\title{
Economic Fluctuation and Business Investment Behavior
}

\author{
Zou Caifen, Yu Qian, Ge Rong
}

(Accounting School,Wuhan Textile University Wuhan, Hubei 430200)

Keywords: Economic fluctuation, investment scale, technological innovation, regional difference Abstract: The impact of economic fluctuations on corporate investment behavior was studies based on the data of of listed companies during 2009 -2015. The result indicated that the better the economic environment is, the larger the scale of capital expenditure would be, and the weaker the intensity of technological innovation. A further Sub-regional study found that there is no significant difference about economic fluctuations in the scale of business investment in the eastern and western areas; there are some differences in the effect of technological innovation. Economic status is positively correlated with technological innovation in the eastern region, economic status is not significant negatively correlated with technological innovation in the central and western regions.

\section{Introduction}

As an important part of GDP, investment is closely related to economic fluctuation. Extensive research found out different paths of the impact of economic fluctuations on investment behavior. Macroeconomic fluctuations put different influence on firms investment scale, efficiency and resource allocation. The macro economic growth led more investment turn to capital projects and infrastructure (Lu Ming, European Navy, 2011), and larger firm investment (Yoon,Ratti, 2011), but in the prosperous economic stage, the capital investment can not fully meet the requirements of high quality production, the enterprises will increased investment in $R \& D$ to promote their innovation capability to improve economic performance (Aghion et al.2007).

As China's economy steps into the "new normal" phase, it gradually turns from factor-driven, investment-driven to innovation-driven economic mode, technological innovation rather than technology imitation has become an important national strategy. Innovation plays an important role in maintaining firm competitiveness (Xinghua Wei, 2013).

Does economic fluctuation have the same effect on investment scale and innovation investment? Do the macroeconomic fluctuation and the microeconomic fluctuation have the same influence on them? Are the regions with different levels of economic development functioning in the same way? The paper contributed to explore such problem.

\section{Literature review and hypothesis}

Keynes's economic fluctuation theory believes that the economy will be cyclical fluctuations: boom-recession-depression-recovery. In the later stages of economic prosperity, as the profit declines, enterprises are more conservative on the investment, and the external demand increases more inhibits the investment behavior; When the enterprise continuous loss, appeared insufficient supply cause crisis, investment is less; To the economic depression stage, the interest rate reduces, the enterprise appears the profit, further expands the production, the profit increases, the economy starts to recover, the enterprise starts to enlarge the investment. In a period of economic prosperity, the productivity of enterprises is greatly improved, the profits are maximized, and enterprises need to invest to maximize the resources. 
Economic fluctuations affect financial development, financial development and investment efficiency was negatively correlated, and making the macroeconomic fluctuations on the investment efficiency of enterprise has a certain impact (Yupeng Wang, Qingming Zhao, 2015).

The economic cycle has certain influence on enterprises the investment behavior. There is a significant difference between the investment and the economic growth in the different stages of the economic cycle ( Yuanmu Zhen, 2012). From the stage of enterprise investment and economic cycle can be found, the main causes of economic fluctuations include large fluctuations of investment of fixed assets, inventory investment and macroeconomic fluctuations are always in the same direction

(Keying Wang, Hongwu Zhang, 2012) . Hence the first assumption was made:

Hypothesis 1: The better the economy, the larger the scale of business investment.

Economic fluctuations and R\&D investment has roughly two effects, one is the "cash flow effect", when the economy is booming, the market demand is high, this will stimulate enterprises with sufficient cash flow to invest R\&D. Companies do not have sufficient cash flow to support them, reducing the burden by reducing $R \& D$ expenditures during times of economic downturn. The other is "opportunity cost effect". In a recession, the opportunity cost of R\&D investment is low, so companies should increase R\&D investment, making the economic cycle into the next round of recovery.

Given the nature of the property rights, state-owned listed companies are generally more likely to be financed to compensate for the shortage of R\&D funds and enhance innovation (Mingqi Jia, Yan Yan, Jianglong Xin, 2015 ), therefore, there is negative correlation between economic growth and technological innovation. Hence the second assumption was made:

Hypothesis 2: The better the economy, the weaker the investment in innovation.

\section{Research design}

\section{Variables selection}

Dependent variables: In this paper, the investment behavior of enterprises as an dependent variable. The investment included in this article refers to the investment activities related to the current economic activities of the company, mainly the purchase and construction of fixed assets and the capital investment expenditure of other long-term assets, cash paid by fixed assets and other long-term assets and the ratio of beginning total assets to measure the investment behavior. Innovation behavior is a form of enterprise investment behavior; this paper selects the ratio of $R \& D$ expenses to operating income as a measure of enterprise innovation.

Independent variables: This paper uses economic volatility as an independent variable. In the study of the economic cycle fluctuation and investment behavior, domestic scholars mostly use annual growth rate of GDP to measure the change of economic cycle. The paper the macroeconomic fluctuation studied use the GDP growth rate of each province, and the growth rate of the enterprise income for the micro fluctuation.

Control variables: In order to get a better research result, the article set up a number of control variables. Enterprise profitability choose return on net assets, the higher the index value, indicating the higher the benefits of investment enterprises, and investment in technological innovation is more assured; this paper takes the natural logarithm of the total assets of the enterprise as the scale. Asset-liability ratio, the index is mainly used to measure the long-term solvency of enterprises, can be used as a proxy variable for corporate capital structure; Increasing the region as a dummy variable, the eastern region is 1 , the central and western regions is 0 . 
Table 1. Variables definition and calculation

\begin{tabular}{|c|c|c|}
\hline Variable & Symbols & Definition \\
\hline Investment scale & INV & $\begin{array}{l}\text { Cash paid for fixed assets and other long-term assets / } \\
\text { Beginning total assets }\end{array}$ \\
\hline R\&D intensity & $\mathrm{RD}$ & R\&D expenses / Operating revenues \\
\hline $\begin{array}{l}\text { Economic } \\
\text { fluctuations }\end{array}$ & $\begin{array}{l}\text { Economi } \\
\mathrm{c}\end{array}$ & $\begin{array}{l}\text { (Current GDP - Previous period GDP)/Previous period } \\
\text { GDP } * \%\end{array}$ \\
\hline $\begin{array}{l}\text { Enterprise } \\
\text { growth }\end{array}$ & Growth & $\begin{array}{l}\text { (Current operating income - Previous period Operating } \\
\text { revenues)/ Previous period Operating revenues }\end{array}$ \\
\hline Profitability & Roe & Net profit / Net assets \\
\hline Enterprise size & Size & The natural logarithm of the company 's total assets \\
\hline Leverage ratio & Lev & Total liabilities in current period / Current total assets \\
\hline Area & Area & $\begin{array}{l}\text { Virtual variable, the eastern region is } 1 \text {, the Other regions } \\
\text { is } 0\end{array}$ \\
\hline
\end{tabular}

Model

In order to test the effect of business cycle fluctuation on innovation behavior and investment scale, this paper establishes model (1) with the scale of investment as the explanatory variable, and a regression model (2) was established with $\mathrm{R} \& \mathrm{D}$ expenditure as the ratio of total assets as the explanatory variable, as follows:

$$
\begin{aligned}
& \mathrm{INV}=\beta_{0}+\beta_{1} \text { Economic }+\beta_{2} \text { Growth }+\beta_{3} \text { Roe }+\beta_{4} \text { Size }+\beta_{5} \text { Lev }+\beta_{6} \text { Area }+\varepsilon \text { (1) } \\
& \mathrm{RD}=\beta_{0}+\beta_{1} \text { Economic }+\beta_{2} \text { Growth }+\beta_{3} \text { Roe }+\beta_{4} \text { Size }+\beta_{5} \text { Lev }+\beta_{6} \text { Area }+\varepsilon \text { (2) }
\end{aligned}
$$

\subsection{Data description}

In this paper, the initial sample of A-share listed companies in China is selected, and the initial samples are selected from the data of 2010-2015. The enterprises with asset-liability ratio greater than 1 and some enterprises with missing financial data and ST companies are excluded. And finally 7362 samples were obtained. The data used in this paper are from the same flush database and China Statistical Yearbook.

\section{Empirical analysis}

\section{Descriptive statistics}

Table 2. Descriptive statistics

\begin{tabular}{c|c|c|c|c|c}
\hline Variable & $\begin{array}{c}\text { Sample } \\
\text { size }\end{array}$ & Mean & Minimum & Maximum & $\begin{array}{c}\text { Standard } \\
\text { deviation }\end{array}$ \\
\hline INV & 7362 & 0.0915 & 0.00007 & 4.5586 & 0.1148 \\
RD & 7362 & 0.0407 & 0.0003 & 1.6943 & 0.0433 \\
Econom & 7362 & 0.0012 & 0.0076 & 0.2713 & 0.0053 \\
ic & & & & & 0.7623 \\
Growth & 7362 & 0.2137 & -0.7909 & 43.607 & 1.451 \\
Roe & 7362 & 0.0946 & -1.936 & 0.1020 \\
Lev & 7362 & 0.3780 & 0.0075 & 0.9924 & 0.1989 \\
Size & 7362 & 21.5923 & 18.301 & 26.969 & 1.1482 \\
\hline
\end{tabular}

Through Table 2 found that manufacturing enterprises' R\&D input intensity is $4.07 \%$, the overall R \& D at a high level; The average investment scale is $9.15 \%$, the overall level is moderate, but the polarization difference is relatively large; The average GDP growth rate index is 0.012 , the maximum value is 0.2713 , the minimum value is 0.0076 , which indicates that the economic 
development between provinces has some differences. The average income growth rate is 0.2137 , the maximum value is 43.607 , and the minimum is -0.7909 , indicating a large difference in corporate income fluctuations.

\section{Correlation analysis}

Table 3. Correlation analysis

\begin{tabular}{c|c|c|c|c|c|c|c}
\hline & INV & RD & $\begin{array}{c}\text { Economi } \\
\text { c }\end{array}$ & Growth & Roe & Lev & Size \\
\hline INV & 1 & & & & & & \\
RD & -0.008 & 1 & & & & & \\
Econo & $0.178^{* *}$ & $-0.113^{* *}$ & 1 & & & & \\
mic & & & & & & \\
Growth & $0.341^{* *}$ & $-0.038^{* *}$ & $0.123^{* *}$ & 1 & & & \\
Roe & $0.216^{* *}$ & $-0.036^{* *}$ & $0.254^{* *}$ & $0.205^{* *}$ & 1 & & \\
Lev & $-0.097^{* *}$ & $-0.168^{* *}$ & $-0.186^{* *}$ & 0.006 & $-0.166^{* *}$ & 1 \\
Size & $-0.044^{* *}$ & $-0.245^{* *}$ & $0.043^{* *}$ & $0.051^{* *}$ & $0.112^{* *}$ & $0.486^{* *}$ & 1 \\
\hline \multicolumn{7}{c}{ Note: $* * *, * *, *$ represent respectively the significance level of $0.01,0.05$, and 0.1.}
\end{tabular}

Through Table 3 found that there is the correlation between macroeconomic fluctuations and the scale of investment, $R \& D$ intensity, and the growth rate of corporate income and investment scale, R\&D intensity also has a certain correlation. From the perspective of control variables, the relationship between the control variables and firm investment scale is significant, and the relationship with the $\mathrm{R} \& \mathrm{D}$ intensity is also significant. At the same time, we can see that there is no large multicollinearity among the variables. 


\section{Regression analysis}

Table 4. Regression analysis

\begin{tabular}{|c|c|c|c|c|c|c|}
\hline \multirow{2}{*}{$\begin{array}{c}\text { Variabl } \\
\mathrm{e}\end{array}$} & \multicolumn{3}{|c|}{ Model 1} & \multicolumn{3}{|c|}{ Model 2} \\
\hline & $\begin{array}{c}\text { Nationw } \\
\text { ide }\end{array}$ & $\begin{array}{l}\text { East } \\
\text { area }\end{array}$ & $\begin{array}{c}\text { Central and } \\
\text { western }\end{array}$ & $\begin{array}{c}\text { Nationwid } \\
\mathrm{e}\end{array}$ & East area & $\begin{array}{c}\text { Central and } \\
\text { western }\end{array}$ \\
\hline $\begin{array}{c}\text { Constan } \\
\mathrm{t}\end{array}$ & $\begin{array}{c}0.152^{* * *} \\
(5.642 \\
)\end{array}$ & $\begin{array}{c}0.187^{* * *} \\
(5.944 \\
)\end{array}$ & $\begin{array}{c}-0.001 \\
(-0.023)\end{array}$ & $\begin{array}{c}1.51^{* * *} \\
(14.250 \\
)\end{array}$ & $\begin{array}{c}1.56^{\text {*** }} \\
(14.793 \\
)\end{array}$ & $\begin{array}{l}1.394^{* * *} \\
(4.582)\end{array}$ \\
\hline $\begin{array}{l}\text { Econo } \\
\text { mic }\end{array}$ & $\begin{array}{c}0.002^{* * *} \\
(9.047 \\
)\end{array}$ & $\begin{array}{c}0.002^{* * *} \\
(6.809 \\
)\end{array}$ & $\begin{array}{l}0.003^{* * *} \\
(7.650)\end{array}$ & $\begin{array}{l}-0.908^{* * *} \\
(-9.350)\end{array}$ & $\begin{array}{l}-1.008^{* * *} \\
(-9.894)\end{array}$ & $\begin{array}{l}-0.887^{* *} \\
(-3.453)\end{array}$ \\
\hline Growth & $\begin{array}{c}0.046^{* * *} \\
(27.78 \\
1)\end{array}$ & $\begin{array}{c}0.097^{* * *} \\
(-35.65 \\
6)\end{array}$ & $\begin{array}{l}0.16^{* * *} \\
(9.783)\end{array}$ & $\begin{array}{l}-2.263 \\
(-0.402)\end{array}$ & $\begin{array}{c}-0.56 \\
(-0.614)\end{array}$ & $\begin{array}{c}0.026 \\
(0.023)\end{array}$ \\
\hline Roe & $\begin{array}{c}0.101^{* * *} \\
(10.15 \\
7)\end{array}$ & $\begin{array}{c}0.06^{* * *} \\
(5.105 \\
)\end{array}$ & $\begin{array}{l}0.78^{* * *} \\
(4.999)\end{array}$ & $\begin{array}{c}-14.905^{\text {*** }} \\
(3.814)\end{array}$ & $\begin{array}{c}-2.994 \\
(-0.753)\end{array}$ & $\begin{array}{l}-42.64^{* * * *} \\
(-3.899)\end{array}$ \\
\hline Size & $\begin{array}{c}-0.005^{\text {*** }} \\
(-3.712 \\
)\end{array}$ & $\begin{array}{c}0.006^{* * *} \\
(-4.386 \\
)\end{array}$ & $\begin{array}{c}0.020 \\
(1.180)\end{array}$ & $\begin{array}{c}-3.796^{* * *} \\
(-7.614)\end{array}$ & $\begin{array}{c}-4.013^{* * *} \\
(-8.132)\end{array}$ & $\begin{array}{l}-3.038^{*} \\
(-2.128)\end{array}$ \\
\hline Lev & $\begin{array}{c}-0.016^{*} \\
(-2.229 \\
)\end{array}$ & $\begin{array}{c}-0.012 \\
(-1.495 \\
)\end{array}$ & $\begin{array}{l}-0.043^{* * *} \\
(-3.569)\end{array}$ & $\begin{array}{c}-42.664^{* * *} \\
(-15.058 \\
)\end{array}$ & $\begin{array}{c}-44.972^{* * *} \\
(-16.090 \\
)\end{array}$ & $\begin{array}{l}44.035^{* * * *} \\
(-5.164)\end{array}$ \\
\hline $\mathrm{F}$ & 266.88 & 349.55 & 52.808 & 126.507 & 137.97 & 15.619 \\
\hline$A d j-R^{2}$ & 0.153 & 0.231 & 0.142 & 0.079 & 0.106 & 0.045 \\
\hline obs & 7362 & 7362 & 7362 & 7362 & 7362 & 7362 \\
\hline
\end{tabular}

Note: () is the $\mathrm{p}$ value, superscript $* * *, * *, *$ represent respectively the significance level of 0.01 , 0.05 , and 0.1 .

From Table 4, there is a significant positive correlation between GDP growth rate and investment scale in Model $1(\beta=0.002, \mathrm{P}<0.05)$, while the income growth rate and investment scale significantly positive correlation $(\beta=0.046, \mathrm{P}<0.05$ ), which is in accordance with Hypothesis 1 . The GDP growth rate in Model 2 is significantly negatively correlated with R\&D intensity $(\beta=-0.908$, $P<0.05)$, revenue growth is negatively correlated with $R \& D$ intensity $(\beta=-0.263, P>0.05)$, but not significantly. Because of the differences in regional economic development, sub-regional observations found that regional scale of investment pro-cyclical, economic fluctuations in the eastern region of the impact is slightly less than the central and western regions. The growth of macro GDP has a significant negative correlation with the R\&D investment. The impact of the eastern region is slightly larger than that of the central and western regions. The impact of firm's economic fluctuation on $R \& D$ intensity is more obvious among regions. For the eastern part of the enterprise income growth and R \& D intensity was negatively correlated, but not significant; while in the central and western regions, corporate income and $\mathrm{R} \& \mathrm{D}$ investment was positively correlated, the results were not significant. 


\section{ROBUSTNESS TEST}

According to the need of research, this paper carries out the robustness test on the result of investment scale and R\&D intensity by changing the core variable index. The economic fluctuation of micro-enterprise level can be measured by income, profit, employment, therefore, this paper selects A-share manufacturing industry 2010-2015 growth rate of the number of employees to replace the income growth rate, with inter-provincial income growth rate instead of inter-provincial GDP growth rate, as follows.

Table 5. Regression analysis

\begin{tabular}{c|c|c}
\hline Variable & Model 1 & Model 2 \\
\hline constant & $0.185 * * *$ & $0.138 * * *$ \\
& $(5.803)$ & $(4.312)$ \\
Economic & $0.114 * * *$ & $-0.044 * * *$ \\
& $(4.458)$ & $(-5.039)$ \\
Employment & $0.036 * * *$ & -0.002 \\
& $(11.580)$ & $(-0.828)$ \\
Roe & $0.067 * * *$ & $-0.047 * * *$ \\
& $(4.179)$ & $(-4.089)$ \\
Lev & $-0.045 * * *$ & $-0.046 * * *$ \\
& $(-3.643)$ & $(-5.151)$ \\
Size & $0.004 *$ & $-0.003 *$ \\
F & $(1.917)$ & $(-1.876)$ \\
Adj-R & 61.589 & 133.698 \\
& 0.166 & 0.080
\end{tabular}

It can be seen that the model 1 inter-provincial income growth rate is positively correlated with investment scale $(\beta=0.114, \mathrm{P}<0.05)$, and a significant positive correlation between employee growth rate and investment scale $(\beta=0.036, P<0.05)$; The inter-provincial income growth rate is negatively correlated with $R \& D$ intensity in model $2(\beta=-0.044, P<0.05)$, staff growth is negatively correlated with R \& D intensity $(\beta=-0.002, P>0.05)$, but not significant. Compared with the results of using the growth rate of enterprise income and the provincial GDP growth rate, the change is not significant, and the data result is proved to be stable and reliable again.

\section{Conclusion and implication}

Based on the study of data found that economic fluctuation has important influence on investment scale and R\&D intensity from macro-micro and micro perspective. The better the economic situation, the scale of investment, technological innovation intensity is weaker. Further sub-regional study found that economic fluctuations in the scale of investment for enterprises are not very clear differences; there are some differences in technological innovation. There is a positive correlation between the economic situation and technological innovation in eastern areas. There is a negative correlation between the economic situation and technological innovation in the central and western regions, and the results are not significant.

Get the following inspiration: First, irrational investment structure and the scale of investment has always been a difficult problem, macroeconomic and microeconomic discoveries have a great impact on the capital investment of enterprises. In the new economic environment, it is necessary to 
take provincial investment - high efficiency route, make rational use of funds and ensure the economic efficiency of enterprises. Second, the impact of economic changes on R\&D intensity of enterprises is very big. Appropriate fiscal and monetary policies can reduce changes brought by economical fluctuations to R\&D investment, enabling enterprises to research and development. Economic tightening will make corporate financing constraints intensity becomes larger, for different periods of time should develop different innovation policies, and the use of strong tax incentives to provide incentives, the government has increased the subsidy of science and technology funds, and the enterprises have expanded the R\&D financing channels and alleviated the problem of financing constraints. Third, for the GDP and corporate growth rate on the impact of investment behavior can not take a "one size fits all" approach. For the region, in the stage of rapid economic development, excessive investment in the eastern region should be suppressed. For the western innovation-deficient areas, effective encouragement measures should be taken to relax investment restrictions and increase government subsidies.

\section{REFERENCES}

[1] Ming Lu,Haijun Ou.(2011). High Growth and Low Employment: Empirical Study on Government Intervention and Employment Elasticity, World Economy, (12).

[2] Justiniano, Alejandro, Gorgio E. Primiceri, and And rea Tambalotti. (2011). Incestment Shocks and the Relative Price of Investment, Review of Economic Dynamics, (14).

[3] Daniele, Vittoria. (2011). Natural Resources and the 'Quality' of Economic Development, Journal of Development Studies,(47).

[4] Xinghua Wei, Weimin Hou. (2007)The Choice of Chinese Economic Growth Mode and Its Transformation, Economic Research,(7).

[5] Yupeng Wang, Qingming Zhao. (2015). Financial Development and Macroeconomic Fluctuation - Empirical Evidence from 214 Countries, International Finance Research, (2).

[6] Yuanmu Zhen. (2012). Business Cycles, Cash Holdings and Corporate Investment Behavior, Nanjing: Nanjing People Learn.

[7] Mingqi Jia, Yan Yan, Jianglong Xin. (2015). Business Cycle, Industry Periodicity and Enterprise Technological Innovation - Based on Empirical Data of Listed Companies, Business Studies, (9).

[8] Keying Wang, Hongwu Zhang. (2012). An Analysis of the Correlation between Stock Investment and Macroeconomic Fluctuation in China, Enterprise Economy, (4). 